\title{
Manažerské rozhodování při řízení kvality školy
}

\author{
Jan Voda \\ Univerzita Karlova, Pedagogická fakulta, Katedra primární pedagogiky
}

Redakci zasláno 22. 3. 2012 / upravená verze obdržena 15. 7. 2012 / druhá upravená verze obdržena 5. 8. 2012 / k uveřejnění přijato 6. 8. 2012

\begin{abstract}
Abstrakt: V textu je představena metodologická aplikace design-based research při zjišt’ování závislosti manažerského rozhodování a kvality školy. S oporou o teoretické principy rozhodování a koncept kvalitní školy bilancujeme reálné výsledky rozhodovacích procesů ve fázi zakládání školy a tvorby školního kurikula. Jedná se o soukromou bilingvní základní školu s prvním stupněm. Východisko kvality této školy je spatřováno $\mathrm{v}$ kvalitě rozhodovacích procesů. V rozpětí čtyř let sledujeme, jak v cyklickém procesu analýza-návrh-evaluace-nový návrh dochází k posunům a přehodnocování původních rozhodnutí. Na základě získané procesní zkušenosti nabízíme interpretace, které mohou zpětně přispět k rozšíření poznání rozhodovacích procesů managementu škol. Současně zužitkováváme výsledky výzkumu k vytříbení praktického řešení ve prospěch zkoumané školy.
\end{abstract}

Klíčová slova: kvalita školy, základní škola, kurikulum, rozhodovací proces, designbased research

\section{1 Úvod}

Nově založené pojetí vzdělávacího paradigmatu staví na schopnosti škol rozvíjet se zevnitř (Spilková, 2005). Koncept vnitřní proměny školy směřuje k cílevědomému budování školního prostředí a komunity podporující učení a vyučování. Nezbytnou podmínkou k naplnění této vize je na jedné straně dostatečná profesní autonomie, která zmocňuje učitele/ředitele k samostatnému rozhodování a jednání a přisuzuje mu odpovídající stupeň odpovědnosti. Z druhé strany je zcela zásadní, aby byli učitelé/ředitelé schopni uvědomělé a kritické aplikace nejlepších dostupných vědeckých poznatků při rozhodování o postupu v konkrétních otázkách vyučování a ř́zení školy - aby kombinovali „praktickou zkušenost s informacemi zjištěnými systematickým výzkumem“ (Dvořák \& Vyskočilová, 2002, s. 39). To předpokládá „nový typ konkrétního pedagogického rozhodování, které čerpá jednak z databází o výsledcích výzkumu, jednak ze zobecněných profesionálních zkušeností učitelů“ (rozhodování založené na důkazech, evidence-based decision; Mareš, 2010, s. 50). Tím se navozuje otázka, jak „nastavit vztah mezi teoretiky/ 
výzkumníky a praktiky, aby se teoretické/výzkumné poznatky přenášely a využívaly způsobem, který by umožňoval praxi žádoucím způsobem měnit a rozvíjet" (Janík, Slavík, \& Najvar, 2011, s. 44). V citované práci autoři bilancují tři možné formy těchto vztahů. $\mathrm{V}$ prvním případě jsou vztahy abstrahovány od jakékoli kooperace - výzkumné poznatky jsou praktikům předkládány bez významnějšího angažmá výzkumníků na jejich interpretaci a zužitkování v praxi. Formy těsnější spolupráce představují vztahy, kdy výzkumník poskytuje praktikovi poznatky založené na zkoumání praxe, jichž praktik využívá $\mathrm{k}$ rozvíjení praxe a poskytuje zpětnou informaci výzkumníkovi o jejich využitelnosti. Třetí varianta uvažuje o splynutí role výzkumníka a role praktika v jedné osobě. Zkoumající praktik reflektuje sebe a svoji praxi, aby mohl na základě tohoto poznání svoji praxi zlepšovat. „Výzkum mu napomáhá lépe porozumět tomu, proč jsou jeho určité praktiky úspěšné více a jiné méně“ (Janík, Slavík, \& Najvar, 2011, s. 44).

Poslední ze jmenovaných konstelací nabízí skutečně jedinečné příležitosti pro vstup do zkoumané reality. Provádět výzkum tohoto charakteru znamená „být doslova tam, kde dochází laicky řečeno k přímé akci, být v centru dění, získávat data a "svědectví takzvaně z první ruky" (Bassey, 1999, podle Sedláček, 2007, s. 99). Takto vedený výzkum však z druhé strany vyžaduje mimořádnou opatrnost vzhledem $\mathrm{k}$ problematice subjektivity badatele. Vědecké poznání usiluje o objektivitu. Při posuzování objektivity výzkumu je často zdůrazňována neutralita badatele (Pelikán, 2004, s. 25-36), který nezasahuje do běhu věcí a současně se vyhýbá subjektivním interpretacím (v ideálním případě by měla výzkumná data hovořit sama za sebe). Přísně objektivní postoj činí badatele pasivním pozorovatelem externích jevů, vylučuje možnost jakéhokoli ovlivňování. Jeho subjektivita by měla být minimalizována až na nulu. Na druhé straně umožňuje subjektivní náhled a osobní zkušenost lépe porozumět předmětu bádání. Distancováním sebe sama od předmětu výzkumu dosáhneme právě a jedině větší distance. Na pedagogickém poli poukázal na tuto skutečnost Tonucci (1991), když zdůrazňuje nezbytnost přejít od výzkumu školy (jako objektu) k výzkumu ve škole a se školou se všemi obtížemi a komplikacemi, které to obnáší:

Je třeba pracovat s učiteli a s jejich pomocí poznávat jinak nepoznatelnou realitu: škola je totiž jako citlivý ekosystém, který se hluboce změní, když do něj vstoupí nový prvek. Přítomnost badatele nebo jen aparátů na pozorování a registraci vyvolává značné změny v chování. (Tonucci, 1991, s. 23) 
Subjektivitu badatele lze tedy vnímat i jako přínos pro pochopení zkoumaných jevů, i když je nutné mít neustále na zřeteli, že subjektivní přístup je spojen s nebezpečím sebeprojekce výzkumníka, ztrátou kritické citlivosti a schopnosti rozlišovat, kde končí objektivnost a začíná sebeklam.

Toto metodologické dilema se snaží ilustrovat autor příspěvku na konkrétním výzkumném případu z vlastní praxe, kdy v období 2005 až 2010 zastával dvojjedinou roli: byl zároveň ředitelem zkoumané školy a současně výzkumníkem - autorem disertační práce (Voda, 2010). Předmětem výzkumu byla soukromá Základní škola s rozšířenou výukou jazyků Magic Hill. Škola byla založena v roce 2005 , tedy souběžně se zahájením řešení disertačního výzkumu, jako „pokusná škola“ pouze s prvním stupněm, př̌ičemž byly sledovány dvě roviny cílů: (1) naplnění vize kvalitní školy z pragmatického hlediska potřeby zřizovatele udržet školu na trhu vzdělávání; (2) řešení výzkumného problému, jaká manažerská rozhodnutí jsou (v daných podmínkách) klíčová pro nastolení vysoké kvality školy.

Kumulací funkce badatele a ředitele školy byly nastaveny ideální př́ležitosti pro sběr výzkumných dat. Nalézt podmínky a dostatečnou koncentraci pro vědecký výzkum za běhu školních (manažerských) a třídních (učitelských) pracovních povinností však bylo velkou výzvou a vytvářelo značné nároky. Překrytím funkcí teoretického badatele a praktika $v$ jedné osobě jsme si nicméně slibovali získat nový vhled do studované reality z perspektivy angažovaného subjektu (ředitele školy) reflektovaný skrze teoretickou bázi pedagogické vědy a uchopený nástroji pedagogického výzkumu (výzkumník), a očekávali jsme potenciálně vytěžit nové poznatky a náhledy, které nelze získat a vysvětlit z izolované pozice žádného z nich.

\section{Rozhodování v procesu řízení kvality školy}

Z dostupných empirických výzkumů (Pol et al., 2005; Spilková, 2005) i teorie managementu (Slavíková, 2003; Prášilová, 2006; Veber, 2005) je zřejmé, že fungování a budoucí vývoj školy zásadním způsobem ovlivňují kvalita a výsledky rozhodovacích procesůํำ Jedná se o široké spektrum odborných

\footnotetext{
Psychologické aspekty rozhodování viz např. Bedrnová \& Provazník (1991), Skořepa (2005). Z hlediska řízení představuje rozhodování jednu z nejvýznamnějších aktivit, které manažeři v organizacích realizují. Manažerské rozhodování je jádrovou složkou manažerských funkcí (zejména plánování), jeho cílem je určitý kvalitativní stav organizace (školy), kterého se má dosáhnout řešením tzv. rozhodovacího problému; srov. Fotr et al. (2006).
} 
rozhodnutí, jimiž může učitel/ředitel ovlivnit vývoj školy prostřednictvím velkých i malých, nápadných i nenápadných kroků, s vědomím dalekých perspektiv i v bezprostřední reakci na situaci.

\subsection{Vliv subjektu rozhodování}

Takové rozhodování, které má na zřeteli maximalizaci dosažení zamýšlených cílů, v němž se rozhodovatel snaží systematicky vyhledávat nejlepší možná řešení, lze z hlediska teorie rozhodování označit za racionální. Právě racionalita je ztotožňována s kvalitou rozhodování (Fotr et al., 2006, s. 34-35). Při řešení rozhodovacích problémů $\mathrm{v}$ praxi však existují určité faktory označované jako bariéry racionality, z nichž řada má svůj zdroj př́ímo $v$ rozhodovateli (subjektu rozhodování) samém. Mezi tyto bariéry patří např. omezená schopnost člověka zpracovávat informace, omezený rozsah jeho poznání, limitovaná schopnost člověka formulovat a řešit složité rozhodovací problémy apod. Poznatky empirických výzkumů rozhodovacích procesů ukazují, že subjekty mají tendenci strukturovat rozhodovací problémy ve světle vlastních zkušeností, při shromaždování informací mají lidé sklon vyhledávat takové informace, které jsou v souladu s jejich vlastním chápáním rozhodovacího problému, a rovněž angažovanost rozhodovatele pro určitou variantu řešení problému snižuje jeho objektivitu chápání a hodnocení ostatních variant. Z psychologického hlediska navíc nelze rozhodování redukovat výhradně na racionálně utilitaristická hlediska, protože se v něm uplatňují též iracionální faktory. Konečným aspektem každého rozhodnutí je emoce v jeho pozadí. Vedle rozhodnutí, která lze zdůvodňovat čistě racionální analýzou nebo empirickými poznatky, stojí ta, která je nutno nahlížet spíše bezprostřední intuicí. Při intuitivním myšlení se jednotlivé články souvislého procesu myšlení dostávají pod práh vědomí a jeho závěry se pak objevují náhle jako nápad nebo vnuknutí - reflexivní, automatické zaujetí stanoviska, aniž by se člověk musel nejdřive rozmýšlet a rozhodovat. To nám propůjčuje rozhodnost a jistotu zejména při řešení každodenních problémů. Bez ní by se člověk musel znovu a znovu pouštět do dlouhých, namáhavých a obtížných úvah (Nakonečný, 1997).

\subsection{Rozhodování za nejistoty}

Pro management školy představuje každé klíčové (strategické) rozhodnutí dilema, nebot' se zpravidla jedná o zásahy do složitých, dlouhodobých dějů a na otázky neexistují jednoznačné univerzální odpovědi. Význam a závažnost rozhodování spočívá především v tom, že kvalita a výsledky těchto procesů 
zásadním způsobem ovlivňují efektivitu, at' už na úrovni výkonových parametrů učitele, školy, či celého vzdělávacího systému. Mnohá minulá rozhodnutí představují omezení v současnosti, a tím determinují současné rozhodovací procesy. Stejně tak současná volba určitého rozhodnutí ovlivňuje budoucí rozhodování tím, že vymezuje budoucí zaměření akcí a tím omezuje/vylučuje výběr určitých variant. V reálných situacích navíc subjekt rozhodování disponuje pouze omezeným rozsahem informací, má limitované schopnosti řešit rozhodovací problémy i nedostatečné zdroje/kapacitu k pečlivému hledání a hodnocení všech variant. Nejde tedy o to, že by se rozhodovatelé „nechtěli chovat racionálně, ale že jim jejich vnitřní omezení i omezení okolí často brání k dokonalému rozhodování" (Fotr et al., 2006, s. 34).

Další úskalí představuje skutečnost, že důsledky rozhodnutí nejsou předurčeny pouze rozhodnutím samým, ale současně i mnoha dalšími faktory, které nemůže rozhodovatel bud' zcela, nebo alespoň z části ovlivňovat. Pro úplný popis těchto neznámých externích faktorů se používá termín „stav světa“ (state of the world; tamtéž, s. 25). Kdyby rozhodovatel věděl, který stav světa nastane (znal by hodnoty externích faktorů), mohl by s jistotou předvídat důsledky všech svých rozhodnutí a podle toho zvolit nejlepší akci. V případě rozhodování za jistoty (tzn., že rozhodovatel s jistotou ví, který stav světa nastane) zaručuje kvalitní rozhodnutí vždy příznivé výsledky realizovaného rozhodnutí. Velmi často ale rozhodovatel neví, který stav světa nastane, a může než domýšlet, které stavy světa jsou možné. V praxi tak obvykle pracujeme s větší či menší mírou rizika (nejistoty), tj. s nemožností spolehlivě stanovit budoucí hodnoty faktorů ovlivňujících řešení daného problému, a proto ani obvykle neexistuje jedno jediné správné (optimální) rozhodnutí. To je typické zejména u špatně strukturovaných rozhodovacích problémů, které jsou svým charakterem vždy do určité míry nové a neopakovatelné. Rozhodování v záležitostech kvality školy představuje právě takový typ problému. Jestliže např. Rýdl $(2003$, s. 37) na jedné straně uvádí, že odpovědět na otázku Co je dobrá škola? můžeme pouze za předpokladu, že máme „představu o budoucí společnosti, k jejímuž rozvoji má škola přispívat", potom Hammer (2002, s. 240) naopak vyzývá: „Zapomeňte na plánování budoucnosti na pět let dopředu; zdá se, že pohlédnout jen za horizont nejbližších dvanácti měsíců je nad síly kohokoli z nás." Scénáře pravděpodobného budoucího vývoje školství (Kotásek, 2004) naznačují, jak široká je varieta možných stavů na ose rescholarizace - descholarizace, jichž může škola v příští dekádě nabývat. 


\subsection{Kvalita školy jako vágní východisko manažerského rozhodování}

Další překážku dokonalého racionálního rozhodování lze spatřovat v oblasti cílů vzdělávání, které Spilková (2002, s. 24) považuje za základní vztahový rámec pro posouzení kvality školy. „Za kvalitní, dobře fungující, efektivní školu je považována taková škola, která směřuje, co nejvíc se přibližuje k těmto cílům a je úspěšná v jejich naplňování." V České republice však dosud postrádáme základní dokument s rozpracovanými cíli vzdělávání a prostředky k dosažení těchto cílů a s jednoznačně formulovanou konkretizací představ o kvalitě ve vzdělávání a kvalitní škole - Národní program vzdělávání. ${ }^{2}$

Kvalita školy zároveň představuje velmi relativní koncept, který různí zaangažovaní hodnotitelé (rodiče, žáci, učitelé, představitelé školské politiky apod.) posuzují ze zcela odlišných hledisek (Pol, 2007, s. 42-43). Vedle toho uvádí Rýdl (2003, s. 47) na základě srovnání řady katalogů znaků „dobrých“ škol z různých zemí a od různých autorů, že ,jen velmi obtížně vytvoříme uzavřený a delší dobu funkční katalog znaků „dobré školy“, protože nelze postihnout všechna specifika jednotlivých škol a jedinečnost jejich tvůrců a provozovatelů při reakcích na nově se objevující společenské potřeby a výzvy“.

Shora uvedené momenty ilustrují, v čem spočívá obtížnost manažerského rozhodování při řízení kvality školy. Z druhé strany jsou k dispozici teoretické i výzkumné studie (European Commission, 2001) a praktické zahraniční manuály (Common assessment framework, 2007), jejichž autoři koncept kvalitní školy rozpracovali. Široké pojetí kvality ve vztahu ke vzdělávání uvádí např. Jirečková (2011, s. 71-72) odkazem na Harveyho (1993): kvalita znamená výjimečnost, tedy něco, co není dosažitelné pro všechny; dokonalost, kdy vše probíhá správně napoprvé; naplnění účelu; efektivitu za daných finančních podmínek; přidanou hodnotu. $V$ užším pojetí směřují výzkumy kvalitní školy k taxonomiím faktorů, které charakterizují efektivní školu. $V$ pedagogických vědách sledujeme četné pokusy o vytvoření různých modelů, které převážně vznikaly na podkladě empirických výzkumů. Dosud známé návrhy znaků dobré školy poskytují přehled o postupném vývoji jejich struktury. Zatímco v prvních pokusech z počátku 20. století se kvalitativní ukazatele omezovaly pouze na obsah a metody vyučování, ve 2 . polovině 70. a v průběhu 80 . let už byly seznamy rozšířeny o znaky týkající se také

§3 zákona č. 561/2004 Sb., o předškolním, základním, středním, vyšším odborném a jiném vzdělávání (školský zákon) 
organizace vnitřní práce školy. Současné katalogy znaků (v českém prostředí např. Spilková, 2002; Ryška, 2008; Tupý, 2008) zahrnují i skupiny parametrů vztahujících se $\mathrm{k}$ „vnějšímu prostředí školy, jejímu řízení, plánování budoucnosti a zejména k celkové podobě školy (klimatu) včetně spokojenosti zainteresovaných subjektů“ (Rýdl, 2003, s. 46).

\subsection{Pojetí kvality školy pro potřeby výzkumu}

V rámci našeho výzkumu školy Magic Hill jsme založili pedagogický projekt na atributech kvality uváděných $\mathrm{v}$ odborné literatuře, $\mathrm{s}$ očekáváním, že výstupem bude kvalitní, dobrá škola. Teoretický fundament výzkumu se opírá o dva dominantní zdroje, které samy o sobě jsou koncipovány na metaanalýze předchozích národních a mezinárodních výzkumů. Rozsáhlé a metodologicky rozmanité zpracování problematiky kvality (ve smyslu souvislosti školních výsledků a různorodých faktorů vystihujících oblasti vztahu ke škole, vztahů ve škole, učitelského sboru apod.) poskytly jednak výstupy z projektu Kvalita II - Kvalita škol a hodnocení výsledků vzdělávání. Na základě indikátorů $\mathrm{k}$ vytvoření typologie škol z hlediska kvality autoři uvádějí: „Celkovělze shrnout, že kvalitu škol je možné popsat třemi základními dimenzemi. Jednou dimenzí je školní klima, druhou struktura a zdroje a třetí vztahy. Právě třetí uvedená dimenze má nejvýraznější vliv na výsledky žáků“ (Ryška, 2008, s. 59).

Druhým zdrojem byly nálezy v rámci výzkumného projektu Pedagogické fakulty UK v Praze Rozvoj národní vzdělanosti a vzdělávání učitelů v evropském kontextu, v rámci něhož byly provedeny analýzy zahraničních teoretických přístupů a relevantních výzkumů, na jejichž základě vznikaly modely kvalitní, efektivní školy (Schools and quality..., 1989; High-quality education..., 1992; Measuring the quality..., 1995; European Commission, 2001), a hlouběji objasněny faktory kvalitního fungování školy (Hopkins, 1990; Purkey-Smith, 1983; Mortimore, 1989; Sheerens, 1996). Projekt vyústil do zpracování a metodou př́padové studie ověřovaného modelu kvalitní školy, jenž zahrnoval katalog následujících znaků: (1) jasná filozofie školy, (2) kvalitní systém řízení školy, (3) tvorba školního kurikula, (4) kvalitní učitelský sbor, (5) převažuje progresivní didaktická koncepce výuky, (6) autenticita školy (Spilková, 2002, s. 29-31). Autoři uvádějí, že se potvrdila „funkčnost zvolených kritérií dobře vystihujících podstatné rysy kvalitní školy“ a „zvolená metodologie se ukázala jako vhodná jak pro vnější evaluaci, tak také pro sebeevaluaci školy". 


\section{Cíl a metodologie výzkumu}

V našem výzkumu jsme si kladli otázku, jaká rozhodnutí jsou klíčová pro pedagogický koncept školy (explicitně vyjádřený ve školním vzdělávacím programu - zejména filozofie školy a výchovné a vzdělávací strategie), jaké efekty/charakteristiky školy (zvláště pedagogické podmínky) navozují. Jak jsme již uvedli výše, objektem výzkumu byla nově založená soukromá škola s prvním stupněm na okraji hlavního města. Počínaje záŕím 2006 byla každým školním rokem otevřena jedna první třída (1. ročník) s kapacitou 15 žáků. Všech pěti ročníků (s cílovou kapacitou 75 žáků) tedy škola dosáhla až v roce 2010/11. Klíčová manažerská rozhodnutí však byla učiněna ještě před zápisem školy do rejstř́iku škol a školských zařízení ministerstva školství a nástupem prvních žáků (dále první etapa rozhodování) a v prvním roce existence školy (dále druhá etapa). Třetí etapou označujeme modifikace dílčích rozhodnutí na základě procesní zkušenosti s provozem školy.

Cíle výzkumu byly stanoveny následovně:

1. Popsat, analyzovat a reflektovat rozhodovací procesy, způsob jejich implementace a výsledný dopad.

2. Evaluovat celkový koncept ZŠ Magic Hill jako výsledek rozhodovacích procesů managementu školy.

3. Určit klíčové znaky identity takto utvořené školy.

Jako odpovídající metodologickou platformu vhodnou pro takto koncipovaný výzkum jsme zvolili design-based research.

Design-based research (dále DBR) je jedním z terminologických užití odkazujících $\mathrm{k}$ relativně nové výzkumné metodologii založené na dílech Brownové (1992) a Collinse (1992). DBR spočívá ve vytváření konkrétního produktu pro potřeby vzdělávací praxe a v kritickém rozvíjení teorie, na níž je tento produkt založen (Dvořák, Dvořáková, \& Stará, 2008). Základním rysem tohoto př́stupu je, že by použitím rigorózních metod měl současně vést ke vzniku ověřeně funkčního produktu a zároveň obohatit pedagogickou teorii zkušenostmi z evaluovaného zavádění tohoto produktu (Dvořák, 2011, s. 78). Produktem je $v$ našem případě pedagogický projekt nově vzniklé soukromé základní školy a zkušenostní základnu tvoří reflektovaný a evaluovaný rozhodovací proces jako soubor ústředních manažerských rozhodnutí. 
Napříč různými pokusy precizovat definici DBR lze v literatuře vysledovat pět obecných charakteristik, na nichž je DBR založen a které jsou pro něj určující:

\subsection{Pragmatický}

DBR je označován za pragmatický (pragmatic), protože jeho smyslem je s oporou o teorii navrhnout (design) a také uskutečnit řešení nějakého aktuálního problému (Design-Based Research Collective, 2003). Získaná procesní zkušenost zpětně přispívá k rozvíjením teoretického poznání a současně k vytříbení praktického řešení. Hlavním cílem tedy není testovat, zda nějaká teorie funguje, či nikoli (van den Akker, 1999), ale společně vytvářet a rozvíjet teorii i design skrze výzkumný proces, takže teorie poskytuje „reálnou službu“ praxi (Cobb et al., 2003, s. 10). V případě našeho výzkumu představuje konkrétní aktuální problém prosazení kvalitativních znaků dobré školy (Spilková, 2002; Ryška, 2008) do praxe prostřednictvím souboru cílených manažerských rozhodnutí.

\subsection{Zakotvený}

DBR je zakotvený (grounded) jak v teorii, tak i v praxi - teorie je shodně základnou i výstupem DBR. Teorie je trvale rozvíjena a propracovávána skrze výzkumný proces, který slouží jako rámec ověřované inovace. DBR se odehrává ve zcela reálných podmínkách a respektuje komplexnost, dynamiku i limity autentické praxe. Způsob, kterým je veden DBR je tedy značně odlišný od laboratorního experimentu, který pracuje s jedinou proměnnou, má pod kontrolou ostatní faktory a izoluje situaci od reálného světa (Collins, 1999; Collins, Joseph, \& Bielaczyc, 2004). Pokud se týká našeho výzkumu, jeho ukotvení je v teoretických výstupech dvou výzkumných projektů (Spilková, 2002; Ryška, 2008), které jsou aplikovány do tvorby a řízení reálně fungující vzdělávací instituce ZŠ Magic Hill.

\subsection{Interaktivní, opakovaný, flexibilní}

Pokud jde o vlastní výzkumný proces, DBR je charakterizován jako interaktivní (interactive), opakovaný (iterative) a pružný (flexible). Zdůrazňuje se tak nezbytnost spolupráce mezi výzkumníky a praktiky, nebot' mimo tento vztah mohou teoretické intervence proměňovat realitu jen velmi omezeně (Design-Based Research Collective, 2003; Reeves, Herrington, \& Oliver, 2005). V DBR jsou obvykle teorie a praktické intervence dlouhodobě rozvíjeny a pre- 
cizovány v cyklickém procesu analýza-návrh-evaluace-nový návrh (BannanRitland, 2003). Tato nepřetržitá, znovu se opakující povaha design-procesu logicky počítá s mnohem větší pružností než tradiční výzkumné metody. V našem př́padě koresponduje pružnost a cykličnost výzkumu s uplatněním nástrojů zpětné vazby manažerského rozhodování, tj. intenzivního monitorování a hodnocení bezprostřední reakce všech zainteresovaných subjektů školy (žáků, rodičů, učitelů apod.) na konkrétní intervence.

\subsection{Integrativní}

DBR zahrnuje rozmanité metody a přístupy kvalitativního i kvantitativního výzkumu, jimiž se zpracovávají výzkumná data z mnohačetných zdrojů (integrative).Použitírůzných metod současně sloužíkzvýšení důvěryhodnosti výsledků (Wang \& Hannafin, 2005).

V př́padě našeho výzkumu jsme založili sběr dat s oporou o následující zdroje:

1. Introspektivní: systematická reflexe profesních situací s praktickým cílem zlepšování i výzkumným cílem co nejhlubšího ponoru do případu;

2. zpětnovazebné informace kvalitativního charakteru: analýza dokumentace, polostrukturovaný rozhovor s učiteli, rodiči a externími supervizory, pozorování;

3. zpětnovazebné informace kvantitativního charakteru: dotazník, externí evaluační nástroje.

\subsection{Kontextualizovaný}

DBR je usazen do kontextu (contextualized), protože závěry výzkumu jsou propojeny s design-procesem, skrze který byly generovány, i prostředím, v němž byl výzkum realizován (Wang \& Hannafin, 2005). Stejně tak i výsledky našeho výzkumu jsou v těsné vazbě na specifické podmínky školy Magic Hill.

Z uvedeného je zřejmé, že pro DBR je zásadní velmi těsná vazba mezi teorií a praxí, potažmo mezi výzkumníky a praktiky, která odpovídá na potřebu, aby nové výzkumné přístupy „promlouvaly přímo k problémům praxe“ (DesignBased Research Collective, 2003) a vedly k rozvoji sdíleného vědění. Výzkum musí vést ke sdělitelným teoriím (Reeves, 2000), které pomohou komunikovat důležité poznatky učitelům v praxi i ostatním tvůrcům vzdělávání na různých 
úrovních. Badateli jde tedy nejen o porozumění, dokumentaci a interpretaci zkoumaného jevu, ale současně o změnu a vylepšení edukační praxe (Barab \& Squire, 2004).

DBR je př́stup vystavěný na teorii (Cobb et al., 2003). To znamená, že badatel není odkázán výhradně na vlastní intuici a kreativitu, aby mohl činit rozhodnutí o intervenčním designu. Celý proces DBR vyrůstá ze silné existující teoretické báze (Joseph, 2004), testuje ji a prověřuje v autentických podmínkách. Skrze proces DBR badatelé doufají objevit, co z teorie je funkční a co ne a jak to funguje za určitých konkrétních podmínek. DBR byl ale projektován s očekáváním, že badatelé budou systematicky a průběžně upravovat/přizpůsobovat řadu aspektů design-procesu, takže každá úprava je vlastně dalším experimentem, který umožňuje generovat a ověřovat teorii $\mathrm{v}$ autentickém kontextu. Evaluace tak má formativní charakter, protože zjištěná data mohou vést badatele k propracování a vývoji další, detailnější intervence - $\mathrm{v}$ případě výzkumu Magic Hill $\mathrm{k}$ další, inovované verzi pedagogického projektu.

\section{Výstupy z výzkumu: klíčové rozhodovací procesy při tvorbě školy a implementaci školního kurikula}

Nelze pravděpodobně dosáhnout úplného, taxativního výčtu rozhodovacích procesů. V genezi Magic Hill je ale možné vysledovat a zobecnit tři vývojové etapy, pro které jsou symptomatické konkrétní oblasti rozhodovacích problémů.

\subsection{První etapa}

V první etapě vyúst'ují zkušenosti a osobní preference jednotlivých aktérů rozhodovacích procesů do okamžiku zrodu myšlenky založit soukromou školu jako alternativu k tradičnímu pojetí vzdělávání. Tato fáze představuje rozhodování ano/ne (decision whether) a zvažování nejširších kontextů perspektivy soukromého školství, které v dalších etapách významně ovlivní/ omezí další rozhodování. Ve stručném přehledu sumarizuje toto rozhodování tabulka 1. Vstupní etapou rozhodování intervenovat do edukační reality vytvořením nové školy bylo posouzení možností realizace této alternativy/ exkluzivity vzhledem k podmínkám českého vzdělávacího trhu. Významný proinovační potenciál byl identifikován v prostředí soukromého vzdělávání. Očekávání, že soukromé školy budou poskytovat spíše lepší než nejméně stej- 
ně kvalitní vzdělávání jako školy státní, v praxi významně navozuje zejména ekonomický aspekt - rodiče by sotva platili školné za horší vzdělávání svých dětí nebo za to, které lze běžně získat ve státních školách zadarmo. Prostředí soutěže na svobodném trhu nutí učitele soukromých škol k pracovnímu vypětí, k sebezdokonalování, je významným motivem pracovní horlivosti, vůle k výkonu a zájmu o klienta. Současně lze označit soukromý sektor ve vzdělávání za nejvíce autonomní.

Tabulka 1

Strukturovaný prehled cílů a relevantních manažerských rozhodnutí v rámci 1. etapy

\begin{tabular}{ll}
\hline Cx & cíl \\
$\mathbf{R x}$ & $\begin{array}{l}\text { klíčové rozhodnutí } \\
\text { Rx.x dílčí, taktická rozhodnutí }\end{array}$ \\
\hline 1. etapa rozhodování \\
\hline C1 & $\begin{array}{l}\text { V kontextu plošně selhávajícího úsilí o urychlenou a komplexní reformu školy } \\
\text { realizovat vlastní představy o kvalitním vzdělávání, motivovaného především }\end{array}$ \\
& $\begin{array}{l}\text { konceptem otevřeného vyučování. } \\
\text { R1 }\end{array}$ \\
& $\begin{array}{l}\text { Založit vlastním jménem a na vlastní odpovědnost soukromou školu } 1 \text {. stupně jako } \\
\text { R1.1 Škola podstoupí rizika tržního prostředí, do kterého vstupuje s konkrétní } \\
\text { nabídkou vzdělávacích služeb. } \\
\text { R1.2 Rozsah a kvalita poskytovaných vzdělávacích služeb bude zprostředkovávat } \\
\text { nadstandard oproti běžné školské praxi. }\end{array}$ \\
\hline
\end{tabular}

\subsection{Druhá etapa}

Druhá etapa je spojena s konkretizací vize a mise školy formulovaných v první verzi školního vzdělávacího programu a vytvoření vzdělávací nabídky (viz tabulka 2). Je to fáze výběru alternativy z poměrně širokého spektra dostupných pojetí školy, jejich organizačního uspořádání, profilace apod. (decision which). V této etapě rozhodování byly východiskem (1) identifikované potřeby, které rodič jako př́ijemce vzdělávací služby od školy očekává; (2) státem vytýčené definice cílů vzdělávání a žádoucí tendence v souladu s kurikulární reformou; (3) dostupné modely kvalitní, dobré školy a inspirace alternativního školství. Na základě těchto okruhů poznání byla sestavena nabídka, která byla považována za nejvýhodnější kombinaci studijního programu, ceny, personálního obsazení, komunikace, pedagogických prrístupů a metod apod. v legislativním rámci vymezeném zápisem školy do Rejstř́ku škol a školských zařízení Ministerstva školství 
ČR. Tak byly definovány hlavní pilíře pedagogické koncepce školy, jimiž jsou (1) bezpečné prostředí - vstř́cné klima, jež určuje kvalita a podstata vztahů mezi učitelem a žáky a mezi žáky navzájem; (2) individuální přístup k žákům patrný ve větší rozmanitosti učebních metod a individuální formulaci vzdělávacích cílů a hodnocení práce každého žáka; (3) smysluplné učení vyjádřené v mottu školy „S námi bude učení děti bavit“, které je navozováno prostřednictvím integrované tematické výuky; (4) profilace na výuku cizích jazyků - bilingvní prostředí, $v$ němž jsou některé předměty nebo obsahy vyučovány rodilými mluvčími.

Tabulka 2

Strukturovaný přehled cílů a relevantních manažerských rozhodnutí ve 2. etapě (v návaznosti na předchozí etapu)

Cx cíl

Rx klíčové rozhodnutí

Rx.x dílčí, taktická rozhodnutí

2. etapa rozhodování

C2 Žáci budou na konci 5. tř́́dy disponovat pokročilými komunikačními kompetencemi v cizím jazyce.

Žáci budou vnímat znalost cizích jazyků jako samozřejmost, budou k jejich učení přirozeně motivováni.

R2 Vzdělávací program bude zaměřený na rozšířenou výuku jazyků.

R2.1 Žáci budou exponováni cizímu jazyku v maximálním možném čase - výuka bude zahájena od 1. třídy, ideálně v návaznosti na předchozí jazykovou zkušenost žáků z MŠ; některé předměty budou vyučovány bilingvně; v odpoledním čase budou žáci navštěvovat konverzační klub.

R2.2 Cizí jazyky budou přirozeně integrovány do vyučování - výuka bude dvojjazyčná, propojená s tématem (CLIL).

R2.3 Žákům bude zprostředkován perfektní řečový vzor a kulturní zkušenost - výuka v cizím jazyce bude zajišt'ována výhradně rodilými mluvčími.

R2.4 Pokrok žáků v cizím jazyce bude ověřován standardizovanými evaluačními nástroji - mezinárodní Cambridge testy YLE.

C3 Žáci budou v učení dosahovat svého osobního maxima.

Žáci budou exponováni adekvátním cílům a podmínkám učení, tím se zajistí příležitosti k prožívání úspěchu.

Žáci budou ve škole rozvíjet své individuální zájmy a navazovat na předchozí znalosti a dovednosti. 
R3 Škola bude usilovat o poznání osobnosti, vzdělávacích potřeb a možností každého dítěte. Na tomto základě pak bude přizpůsobovat vzdělávání jeho individualitě.

R3.1 Počet žáků v jednotlivých třídách nepřesáhne 15; celková kapacita školy 75 žáků umožní zachovat ráz bezpečného, přehledného, osobního prostředí.

R3.2 Učitelé budou sdílet poznatky o jednotlivých žácích a zohledňovat je při plánování, realizaci a hodnocení. Učitelé si vytvářejí vlastní učební materiály podle konkrétních potřeb.

R3.3 Pedagogický tým bude rozšířen o externího psychologa, speciálního pedagoga.

R3.4 Respekt k dítěti bude manifestován prostřednictvím nedirektivního přístupu a dobrých mezilidských vztahů.

R3.5 Důraz na individualitu žáků bude vyvažován kooperativními aspekty vyučování ve dvojicích/trojicích, diferencovaných skupinách, v rámci celé třídy (komunitní kruh) i školy (school assembly).

R3.6 Žáci budou hodnoceni slovně, v individuální vztahové normě.

C4 V naší škole bude děti učení bavit - vytvořit smysluplný vyučovací obsah, který bude stát za čas a zájem žáků.

R4 Škola bude uplatňovat projektové vyučování, které akcentuje aktivitu žáků, vzdělávání v souvislostech a smysluplnost výuky.

R4.1 Výběr obsahů bude vznikat na úrovni konkrétní třídy.

R4.2 Vyučovací témata musejí mít obsah i použití související se skutečným světem, rozvíjet klíčové kompetence.

R4.3 Rozvrh hodin bude představovat pouze orientační proporci zastoupení jednotlivých vzdělávacích oblastí. Kde je to účelné, bude výuka realizována v integrovaných blocích.

R4.4 Učebnice budou jedním z doplňkových vzdělávacích materiálů, nejsou primární zdrojem.

R4.5 Bude zdůrazněna a podpořena role informační a komunikační technologie ve výuce (počítače a internet ve třídách).

\subsection{Tretí etapa}

Přijetí žáků ke studiu a zahájení školního roku 2006/07 přináší první zpětné vazby, jimiž škola jako učící se organizace vstupuje do třetí etapy rozhodovacích procesů. Na základě cyklického zkušenostního učení se rozhoduje k průběžným modifikacím svých původních cílů, strategií, hodnot. Výraz „učící se organizace“ není tedy vyjádřením stavu, ale procesu - je to škola ve vývoji přinášejícím nové znalosti a zkušenosti, čímž se rozšiřuje i rozhodovací prostředí (decision environment) celé problematiky o nové aspekty. Jednotlivé komponenty pedagogického projektu školy jsou sledovány v čase ve snaze postihnout a reflektovat jejich posuny (významové, obsahové, organizační). Sledujeme, jak se rozhodovací prostředí jednotlivých rozhodovacích problémů v závislosti na čase rozšiřuje, zda a jak se objevují nové informace a alternativy, které vyvolávají potřebu změny a poskytují přesnější podklady pro nové rozhodnutí. Stanovujeme korekční fázi, v níž 
škola usiluje učinit lepší rozhodnutí vzhledem k dřívějšímu. Následující tabulka 3 postihuje právě ty momenty, kdy jsou generována nová rozhodnutí na základě reflektované zkušenosti zavádění pedagogického projektu do praxe. $Z$ uvedeného přehledu je patrné, že oproti rozhodnutím v předchozích fázích jde už o velmi detailní, operativní úpravy v konkrétnostech školního vzdělávacího programu. V jiných případech (srov. R2.3.1 či R4.4.1, tabulka 3) však nová rozhodnutí popírají předchozí, poněvadž se původní předpoklady nepodařilo prosadit.

\section{Tabulka 3}

\section{Strukturovaný přehled modifikací manažerských rozhodnutí ve 3. etapě}

Rx klíčové rozhodnutí

Rx.x.x dodatečné korekce a nová rozhodnutí v rámci 3. etapy (v návaznosti na rozhodnutí v předchozích etapách)

3. etapa rozhodování

R2 Vzdělávací program bude zaměřený na rozšířenou výuku jazyků.

R2.1.1 Žáci budou v odpoledním klubu diferenciováni.

R2.1.2 Výuka matematiky v angličtině bude zahájena až od 2. ročníku.

R2.2.1 Druhý cizí jazyk španělština bude vyučován povinně od 4. ročníku, ve 3. ročníku fakultativně.

R2.3.1 Funkce asistenta v jazykovém vyučování bude zrušena - tím se posílí autenticita edukačního prostředí při výuce angličtiny.

R3 Škola bude usilovat o poznání osobnosti, vzdělávacích potřeb a možností každého dítěte. Na tomto základě pak bude přizpůsobovat vzdělávání jeho individualitě.

R3.3.1 Podpora nadaným žákům bude posílena odbornou supervizí z Centra nadání.

R3.4.1 Pravidla budou důsledně vyvozována s žáky a budou vizualizovaná. Ověřování různých způsobů zpětné vazby žákům o jejich chování.

R3.6.1 Soubor změn týkající se formy slovního hodnocení na vysvědčení, poskytování průběžné zpětné vazby žákům, pojetí žákovského portfolia apod.

R4 Škola bude uplatňovat projektové vyučování, které akcentuje aktivitu žáků, vzdělávání v souvislostech a smysluplnost výuky.

R4.1.1 Soubor projektů je každý rok revidován a rozšiřován o témata budoucího ročníku.

R4.1.2 V osnování projektů se opouští pravidelný 14denní cyklus, témata jsou formulována volněji a dlouhodoběji.

R4.3.1 Změny v rozvrhu (s přibývajícím počtem ročníků se komplikuje organizace rozvrhu učitelů, zejména rodilých mluvčích, která vyvolává potřebu stále více strukturovat i rozvrh jednotlivých tříd).

R4.4.1 Žáci dostanou učebnice na všechny hlavní předměty (rodiče vyžadují učebnice pro vlastní přehled o probírané látce a porovnání výsledků svých dětí).

R4.4.2 Problematika využití učebnic bude jedním z hlavních témat interní diskuse o školním kurikulu a dalšího vzdělávání učitelů. (Revidování obsahů učebnic na jedné straně a tvorba kvalitních vlastních pracovních listů na straně druhé představuje pro učitele vysoké, neúměrné nároky.) 


\subsection{Průběžná evaluace projektu}

Takto koncipovaný projekt školy (vzniklý výslednicí rozhodovacích procesů managementu školy) jsme průběžně evaluovali z odlišných perspektiv:

1. Dotazníkové šetření subjektivního prožívání interních participantů edukační reality školy - rodičů, učitelů „Když se řekne Magic Hill..." (N = 31). Cílem šetření (duben 2009) bylo získat popis pedagogické reality ZŠ Magic Hill, tak jak ji nahlížejí rodiče žáků a učitelé, jako verifikaci udávaných/chtěných charakteristik proklamovaných školou. Dotazník obsahuje 4 otevřené otázky, které se vztahují k charakteristice školy ukotvené v minulosti (otázka 1) a př́tomnosti $(2,3)$ a zaměřené do budoucnosti (4). Cílem šetření je tak postihnout i určitou vývojovou dynamiku. V první otázce Které charakteristiky školy Magic Hill pro Vás byly podstatné, že jste se tenkrát rozhodli prihlásit své dítě k plnění povinné školní docházky/žádat o zaměstnání právě zde? identifikujeme ty charakteristiky školy, které sehrály roli jako někdejší motivátory rodičů/učitelů, vzbudily jejich zájem, vykazovaly dostatečnou atraktivitu. Druhá otázka je ukotvená $\mathrm{v}$ př́tomnosti, tj. operuje s aktuální zkušeností respondenta se školou: Nakolik tyto charakteristiky škole skutečně odpovídají? Poté, co získal náhled na školu „zevnitř“, z každodenního školního provozu, na základě poznané, prožité praxe. Třetí otázka Které další charakteristiky si nyní uvědomujete, že ZŠ Magic Hill vystihují? uvolňuje prostor pro výčet dalších relevantních znaků školy „dnes“. V rámci 4. položky Které charakteristiky školy v Magic Hill postrádáte a jsou pro Vás důležité? sbíráme informace, jež vyjadřují „poptávku“ po doplnění, adaptaci, inovaci pedagogického projektu školy. Tato otázka je zaměřena do budoucnosti a dává škole šanci podle možností uvědomit si vůli respondentů, případně na ni reagovat a implementovat změnu.

2. Obsahová analýza dokumentace z externí evaluace školy prostřednictvím kriteriálního hodnocení České školní inspekce, rozšířená o expertní stanoviska ze supervize a mentoringu a konzultace školního psychologa. Česká školní inspekce navštívila školu 2x, v dubnu 2007 a únoru 2009, pokaždé na žádost Magic Hill. Obě inspekční zprávy jsou dostupné na http://zpravy.csicr.cz/.

3. Statistické zpracování vzdělávacích výsledků žáků poskytující data kvantitativního charakteru: škola cílevědomě vyhledává př́ležitosti k externí evaluaci vzdělávacích výsledků svých žáků. Na národní úrovni se žáci 
zúčastňují srovnávacích testů KALIBRO a SCIO, jsou vysíláni do předmětových olympiád a soutěží (Matematický klokan, Logická olympiáda MENSA). Jazykové kompetence $v$ cizím jazyce jsou ověřovány prostřednictvím mezinárodních testů YLE/KET a CEFLA ${ }^{3}$.

\subsection{Identita školy a bilance manažerských rozhodnutí}

$\mathrm{Na}$ základě získaných informací jsme dospěli k následujícímu výčtu symptomatických znaků školy, které aspirují korespondovat se znaky kvalitní, dobré školy (Spilková, 2002, s. 29-31):

1. Nízký počet žáků ve třídách je významným faktorem klimatu školy. Poskytuje učitelům dostatek kapacity věnovat se každému jednotlivci nejen při vlastním vyučování, ale rovněž při koncipování přípravy na výuku, při hodnocení prací žáka, v kontaktu s rodiči, v diskusích s ostatními učiteli, školním psychologem apod.

2. Koncepce cizího jazyka je integrální součástí ŠVP a vytváří přirozené dvojjazyčné prostředí pro formální i neformální učení. Jazykové kompetence žáků významně přesahují standardní požadavky základní školy.

3. Škola zajišt’uje podnětné, aktivizující prostř̌edí pro vzdělávání žáků a zprostředkovává vzdělávací obsahy, které odpovídají zájmu a potřebám žáků a akcentují požadavek smysluplnosti.

4. Vzdělávací aktivity a činnosti školy směřují k utváření a rozvíjení klíčových kompetencí. Škola naplňuje záměr využívání inovativních výukových strategií, zejména projektových metod, problémových úloh a kooperativních činností, což prokazatelně vede k dosahování funkční gramotnosti žáků.

Současně s těmito (auto)evaluačními závěry vztahujícími se ke škole jako takové bilancujeme cyklický proces design-based výzkumu vlastního rozhodovacího procesu. Dobíráme se tak konkrétních empirických zjištění, jež představujeme ve stručném výčtu v následující tabulce 4 . Čtyři klíčová rozhodnutí na vstupu reprezentují ve své podstatě hypotézu, že realizací těchto rozhodnutí dospějeme k optimálnímu dosažení předsevzatých cílů. Dílčí zjištění potom konstatují, s jakými výslednými efekty se nakonec jednotlivá rozhodnutí realizují v praxi, a slouží k verifikaci hypotézy.

3 YLE - Young Learners English Test, KET - Key English Test, CEFLA - Competence in English as a Foreign Language 


\section{Tabulka 4}

\section{Bilance manažerských rozhodnutí}

\begin{tabular}{|c|c|}
\hline $\mathbf{R x}$ & rozhodnutí na vstupu \\
\hline $\mathbf{Z x}$ & zjištění \\
\hline R1 & $\begin{array}{l}\text { Založit vlastním jménem a na vlastní odpovědnost soukromou školu 1. stupně jako } \\
\text { alternativu tradiční vzdělávací nabídce. }\end{array}$ \\
\hline $\mathbf{Z 1}$ & $\begin{array}{l}\text { Inovační potenciál soukromé školy je zásadním způsobem oslabován fungováním } \\
\text { tržního mechanismu (závislost na poptávce klienta), který odjímá škole svobodu } \\
\text { realizovat na vlastní odbornou odpovědnost nutné, alternativní kroky k dosažení } \\
\text { vysoké kvality. }\end{array}$ \\
\hline R2 & Vzdělávací program bude zaměřený na rozšířenou výuku jazyků. \\
\hline $\mathbf{Z 2}$ & $\begin{array}{l}\text { Vzdělávací výsledky žáků v jazykové oblasti jsou extrémní. Dosažená míra akcelerace } \\
\text { žáků nastoluje otázky skutečného užitku vzhledem k aktuálnímu zužitkování } \\
\text { v mimoškolním životě žáků a rizikưm devalvace při přechodu žákư na školy } \\
\text { 2. stupně. Vysoká míra profilace na jazykové vyučování oslabuje (zužuje) zbývající } \\
\text { vzdělávací oblasti školního kurikula. }\end{array}$ \\
\hline R3 & $\begin{array}{l}\text { Škola bude usilovat o poznání osobnosti, vzdělávacích potřeb a možností každého } \\
\text { dítěte. Na tomto základě pak bude přizpůsobovat vzdělávání jeho individualitě. }\end{array}$ \\
\hline $\mathbf{Z 3}$ & $\begin{array}{l}\text { Organizací vyučování lze vytvořit ideální podmínky pro uplatňování principů } \\
\text { individualizace. Přesto trvale vyvstávají problémy, jak prosadit individualizaci ve } \\
\text { výuce jako samozřejmý a profesionálně zvládnutý atribut výkonu jednotlivých } \\
\text { učitelů. Ukazuje se, že učitelé mnohem lépe zvládají práci s celkem třídy (frontální } \\
\text { výuka) než s jednotlivci (individualizace). }\end{array}$ \\
\hline $\mathbf{R 4}$ & $\begin{array}{l}\text { Škola bude uplatňovat projektové vyučování, které akcentuje vzdělávání } \\
\text { v souvislostech a smysluplnost výuky. }\end{array}$ \\
\hline $\mathbf{Z 4}$ & $\begin{array}{l}\text { Projektového vyučování v pravém slova smyslu se v Magic Hill nepodařilo } \\
\text { dosáhnout. Předsevzaté principy byly uplatněny v realizaci tematického vyučování. }\end{array}$ \\
\hline
\end{tabular}

\section{Diskuse}

Ve shora uvedeném přehledu (tabulka 4) si povšimneme, že skutečného prosazení projektovaných cílů se fakticky nepodařilo dosáhnout, nebo jen do určité míry, popř. se reálné efekty odchýlily od původních záměrů. Sledujeme tedy určitou antinomii rozhodovacího procesu managementu školy stimulujícího potenciality školy ke kvalitativní proměně a širších kontextů, v nichž je vzdělávání ukotveno.

Pokud se týká prvního zjištění, teoreticky lze předpokládat, že svobodný trh je nejlepším regulativním prostředím, které přispívá ke kvantitativnímu růstu a kvalitativní rozmanitosti vzdělávacích příležitostí. Na poli vzdělávání je podstatou fungování tohoto trhu hledání styčných bodů mezi silnými 
stránkami konkrétní školy a konkrétními rodiči (zákazníky), kteří tyto stránky potřebují nebo preferují a ocení. Pokud však nabídka školy „předešla svou dobu", resp. ambice rodičů v roli zákazníků setrvávají v předešlém vzdělávacím paradigmatu, potom nejen že není vytvářen potřebný stimul vysoké kvality, ale inovativní potenciál školy a učitelů je zásadně oslabován, nebot' požadavky na jejich profesní výkon jsou odkloněny a diktát trhu paradoxně znemožňuje prosazení kvalitativní změny.

Druhé zjištění odkazuje k pozoruhodným výsledkům bilingvní výuky s rodilými mluvčími, kdy žáci byli přirozeně exponováni cizímu jazyku obsaženému nejen ve vyučování, ale $\mathrm{v}$ každodenní neformální interakci. Výsledky standardizovaných testů YLE a CEFLA dokazují, že většina žáků je/bude schopna dosáhnout garantované výstupní úrovně jazykových dovedností B1 podle Společného evropského referenčního rámce na stupni přiměřeném jejich životní zkušenosti už ve 4. třídě. Tato úroveň odpovídá v českém prostředí maturitní zkoušce! To je jistě ohromující skutečnost, evokuje však přinejmenším dvě skupiny zásadních otázek: (1) Pokud jsme tak významně akcelerovali jazykovou kompetenci žáků, jaká bude možnost jejich uplatnění na školách druhého stupně? Budou tyto školy s to navázat na jejich dosavadní úroveň? Dokáží individualizovat výuku cizích jazyků do té míry, aby další studium těchto dětí nebylo stagnací? Je to vůbec možné? (2) Jaký je smysl této akcelerace? Jaké praktické využití se v daném věku žáků nabízí? Není jazykové vyučování vzhledem k ostatním vzdělávacím oblastem zbytečně přeinvestované (finančně - za stranu rodičů, ale i pedagogicky - za stranu školy, která by mohla využít potenciál žáků a vzdělávací čas jinak)?

Třetí zjištění se týká individualizace. V podmínkách privátního školství představuje individuální přístup samozřejmou součást nadstandardu služeb. Také proto musí být početžáků, o které se učitel/škola stará, významně omezen pod úroveň běžnou ve státním školství, aby bylo možné každému věnovat tolik času, kolik vyžaduje. Ačkoli jsou podmínky pro individuální přístup $\mathrm{k}$ žákům v Magic Hill nastaveny velkoryse a rozhodnutí o individualizaci je psychologicky jednoznačně podložené argumentem mnohočetnosti individuálních rysů každého žáka, kterými je nutno se zabývat, má-li být jeho učení co nejefektivnější, přesto trvale vyvstávají problémy, jak iniciovat individualizaci ve výuce jako samozřejmý a profesionálně zvládnutý atribut výkonu jednotlivých učitelů. Ukazuje se, že učitelé mnohem lépe zvládají práci s celkem trrídy (frontální výuka) než s jednotlivci (individualizace). 
Šetření tohoto stavu je obsahem zakázky supervize učitelům, která je zajištována prostřednictvím spolupráce s externím subjektem. Předmětem supervizí je vstupní diagnostika pedagogických kompetencí učitelů, vstupní diagnostika třídy, rozbor konkrétních situací a potřeb ve třídě, návrhy řešení a (v případech dlouhodobé spolupráce) zhodnocení posunů oproti předcházejícím supervizím. Supervize představujífinančněa časově náročnou formu profesní podpory, která se však jeví nevyhnutelnou, pokud škola nemá slevit ze svého předsevzetí/rozhodnutí o zavedení individualizované výuky.

Konečně, dlouhodobé sledování vývoje komponenty projektového vyučování v pedagogickém konceptu Magic Hill identifikuje rovněž další zajímavý jev: posun od projektového vyučování k tematické výuce. Zatímco projektovat znamená v pravém slova smyslu uspořádat veškerou učební látku na základě řešení určitého úkolu (projektu), který se blíží skutečné činnosti ze života, tematické vyučování vychází $\mathrm{z}$ určeného tématu, které může obsahově integrovat různé vyučovací předměty. Ústřední téma je $\mathrm{v}$ centru zájmu a vycházejí z něj různá podtémata, která se mohou uskutečňovat v českém jazyce, matematice, pracovních činnostech apod. Chronologicky lze tuto proměnu datovat ke školnímu roku 2007/8, kdy žáci z původní (jediné) první třídy postoupili do 2 . ročníku; s každým dalším rokem lze vysledovat, jak se tato tendence prosazuje stále silněji. Příčinu vysvětlujeme v aktualizaci předmětové složky kurikula ve vyšších ročnících. Pouze v první třídě se překrývá předmětové učivo, tj. nácvik dovednosti čtení, psaní a počítání s praktickým používáním těchto dovedností jako nástrojů učení a poznávání žáků. Od druhé třídy se prosazují specifické předmětové požadavky očekávané výstupy podle Rámcového vzdělávacího programu (např. celá oblast gramatického učiva), které nelze tak snadno a především s takovou intenzitou asociovat $\mathrm{s}$ tématy $\mathrm{z}$ běžného života.

\section{Závěr}

V textu jsme se pokusili doložit, že pedagogické projektování na úrovni koncepce školy vychází $\mathrm{z}$ manažerských rozhodovacích procesů. Tyto procesy jsou jádrem pedagogické tvorby školy a jejich racionalita je ústředním momentem kvality školy. Výsledný produkt rozhodování má své explicitní vyjádření v klíčových pasážích školního vzdělávacího programu (zejména v kapitolách o filozofii školy a výchovně-vzdělávacích strategiích). V praxi konkrétní soukromé prvostupňové školy jsme konsekvence těchto rozhodovacích procesů čtyři roky sledovali a podali jejich strukturovaný 
výčet. Současně jsme pozorovali, jak ve třech identifikovaných etapách došlo k jejich několikanásobné revizi v cyklickém procesu analýza-návrh-evaluacenový návrh. Výzkumná reflexe těchto rozhodnutí se odehrávala jako kritické analyzování souvislostí, př́ícin a následkủ snahy implementovat teoreticky elaborované znaky kvalitní, dobré školy (Spilková, 2002; Ryška, 2008) v praxi, přičemž tyto snahy byly prosazovány skrze subjekt rozhodování - ředitele školy s vědomím rizika všech bariér subjektivity v racionálním rozhodování.

Na základě zjištění, která vyplynula z kauzální analýzy čtyř klíčových rozhodnutí v procesu tvorby školy, můžeme konstatovat, že těžiště rozhodovacích procesů (procesů designování) spočívá v oblasti cílevědomého vytyčování budoucích stavů školy a cest k dosažení jejích žádoucích kvalit. Tyto aktivity ovšem představují jen jednu stranu mince. Druhou stranu lze spatřovat v procesech implementace těchto rozhodnutí ve smyslu řízení činností a zdrojů v daných podmínkách školy. Proměnlivost těchto podmínek vyžaduje neustálý proces funkčních změn iniciovaných v cyklickém rozhodování, které reaguje na nové informace a vynořující se alternativy. To poskytuje přesnější podklady a otevírá prostor pro další nová rozhodnutí. Proces manažerského rozhodování při řízení kvality školy tak zůstává infinitní.

Souběžně s poznatky o vlastních procesech rozhodování jsme se snažili ilustrovat metodologické možnosti zkoumání těchto procesů prostřednictvím design-based research. Z výzkumné reflexe vyplynul jeden zásadní poznatek $\mathrm{k}$ použité metodologii: $\mathrm{v}$ úvodu našeho příspěvku jsme uvedli, že využívání poznatků pedagogického výzkumu může být v praxi omezené, pokud badateléteoretici a učitelé-praktici nejsou v dostatečně těsném kooperativním vztahu. Školu však tvoří/vytvářejí (designují) nejen ředitel a učitelé, ale významnou měrou také rodiče (zákonní zástupci žáků). Ti ve škole reprezentují početní většinu, nikoli bez vlivu na pedagogickou autonomii učitelů, ale i výzkumné (experimentální) záměry badatelů. Chceme-li rozvíjet školu na principu design-based research, potom je nutné jejich postoje a očekávání $\mathrm{v}$ design procesu respektovat. Ve všech rozhodovacích procesech, jakkoli provázaných s teoretickými výdobytky pedagogické vědy, tato skutečnost odjímá rozhodovateli (a v našem př́padě i badateli a designérovi) výhradní postavení a kontrolu. Výsledky pedagogického výzkumu obecně by tedy měly být komunikovány $\mathrm{s}$ velkou mírou naléhavosti nejen směrem $\mathrm{k}$ učitelůmpraktikům, ale rovněž popularizovány mezi rodiči jako uživateli vzdělávací služby. To je úkolem trvalého dialogu s rodiči, v němž škola znovu a zas musí obhajovat své principy a přesvědčivě argumentovat pro hodnoty, které sama - založená současně na teorii i praxi - staví nejvýše. 


\section{Literatura}

Bannan-Ritland, B. (2003). The role of design in research: The integrative learning design framework. Educational Researcher, 32(1), 21-24.

Barab, S., \& Squire, B. (2004). Design-based research: Putting a stake in the ground. Journal of the Learning Sciences, 13(1), 1-14.

Bedrnová, E., \& Provazník, V. (1991). Psychologické aspekty rozhodování. Praha: SPN.

Brown, A. L. (1992). Design experiments: Theoretical and methodological challenges in creating complex interventions. Journal of the Learning Sciences, 2(2), 141-178.

Collins, A. (1992). Toward a design science of education. In E. Scanlon \& T. O'Shea (Eds.), New directions in educational technology (s. 15-22). New York, Springer-Verlag.

Collins, A., Joseph, D., \& Bielaczyc, K. (2004). Design research: Theoretical and methodological issues. Journal of the Learning Sciences, 13(1), 15-42.

Cobb, P., Confrey, J., deSessa, A., Lehrer, R., \& Schauble, L. (2003). Design experiments in educational research. Educational Researcher, 32(1), 9-13.

Collins, A. (1999). The changing infrastructure of education research. In E. Lagemann \& L. Shulman (Eds.), Issues in education research (s. 289-298). San Francisco: Jossey-Bass.

Design-Based Research Collective. (2003). Design-based research: An emerging paradigm for educational inquiry. Educational Researcher, 32(1), 5-8.

Dvořák, D. (2011). Psychologické a epistemologické otázky tvorby kurikula (Disertační práce). Praha: Univerzita Karlova, Fakulta pedagogická.

Dvořák, D., Dvořáková M., \& Stará, J. (2008). Design research - výzkum učebnic prováděný jejich tvůrci. In P. Knecht \& T. Janík, et al., Učebnice z pohledu pedagogického výzkumu (s. 81-89). Brno: Paido.

Dvořák, D., \& Vyskočilová, E. (2002). Didaktika jako věda a nástroj učitele. In Z. Kalhous \& O. Obst, et al., Školní didaktika (s. 17-61). Praha: Portál.

European Commission (2001). European report on the quality of school education. Luxembourg: Office for Official Publications of the European Communities. Dostupné z http://ec.europa. eu/education/policies/educ/indic/rapinen.pdf

Fotr, J., Švecová, L., Dědina, J., Hrůzová, H., \& Richter, J. (2006). Manažerské rozhodování. Postupy, metody a nástroje. Praha: Ekopress.

Hammer, M. (2002). Agenda 21. Co musí každý podnik udělat pro úspěch v 21. století. Praha: Management Press.

Harvey, L., \& Green, D. (1993). Defining quality. Assessment \& Evaluation in Higher Education, 18(1), 9-34.

High-quality education and training for all (1992). Paris: OECD.

Hopkins, D. (1990). Improving the quality of schooling. Lewes: Falmer Press.

Janík, T., Slavík, J., \& Najvar, P. (Eds.). (2011). Kurikulární reforma na gymnáziích. Od virtuálních hospitací $k$ videostudiím. Praha: NÚV.

Jirečková, I. (2011). Kritéria kvality školy z pohledu České školní inspekce a systémů řízení kvality ISO a CAF. Pedagogická orientace, 21(1), 70-84.

Joseph, D. (2004). The practice of design-based research: Uncovering the interplay between design, research, and the real-world context. Educational Psychologist, 39(4), 235-242.

Kotásek, J. (2004). Budoucnost školy a vzdělávání. In E. Walterová (Ed.), Úloha školy v rozvoji vzdělanosti (s. 441-484). Brno: Paido. 
Mareš, J. (2010). Učitelé a doporučení, která dostávají od výzkumníků: pomůže „edukace založená na důkazech"? In H. Krykorková \& R. Váňová (Eds.), Učitel v současné škole (s. 45-56). Praha: FF UK.

Measuring the quality of schools (1995). Paris: OECD.

Mortimore, P. et al. (1989). A study of effective junior schools. International Journal of Educational Research, 13(7), 753-768.

Nakonečný, M. (1997). Encyklopedie obecné psychologie. Praha: Academia.

Pelikán, J. (2004). Základy empirického výzkumu pedagogických jevů. Praha: Karolinum.

Pol, M. (2007). Škola v proměnách. Brno: MU.

Pol, M., Hloušková, L., Novotný, P., \& Zounek, J. (2005). Kultura školy. Brno: MU.

Prášilová, M. (2006). Vybrané kapitoly ze školského managementu pro pedagogické pracovníky. Olomouc: Vydavatelství UP.

Purkey, S. C., \& Smith, M. (1983). Effective schools - a review. The Elementary School Journal, 83(4), 427- 452.

Reeves, T. C. (2000). Socially responsible educational research. Educational Technology, 40(6), 19-28.

Reeves, T. C., Herrington, J., \& Oliver, R. (2005). Design research: A socially responsible approach to instructional technology research in higher education. Journal of Computing in Higher Education, 16(2), 97-116.

Rýdl, K. (2003). Inovace školských systémů. Praha: ISV.

Ryška, R. (Ed.). (2008). Kvalita škol a hodnocení výsledků vzdělávání. Praha: PedF UK, SVP.

Schools and quality: an international report (1989). Paris: OECD.

Sedláček, M. (2007). Případová studie. In R. Švaříček \& K. Šed’ová (Eds.), Kvalitativní výzkum v pedagogických vědách (s. 96-111). Praha: Portál.

Sheerens, J., \& Brummelhuis, A. (1996). Indicators on the functioning of primary schools in twelve European countries. Paris: OECD.

Skořepa, M. (2005). Rozhodování jednotlivce: teorie a skutečnosti. Praha: Karolinum.

Slavíková, L. (2003). Rízení školy a pedagogického procesu. Brno: Paido.

Spilková, V. et al. (2005). Proměny primárního vzdělávání v ČR. Praha: Portál.

Spilková, V. (2002). Koncept kvalitní, dobré školy - model a možnosti jeho zkoumání ve školní praxi. In V. Spilková \& J. Vašutová (Eds.), Rozvoj národní vzdělanosti a vzdělávání učitelů v evropském kontextu (s. 24-39). Praha: Univerzita Karlova, Pedagogická fakulta.

Společný hodnotící rámec. Aplikační př́ručka modelu CAF (Common assessment Framework) pro školy (2007). Praha: Publikační řada NPJ. Dostupné z http://www.csq.cz/res/ data/001/000258.pdf

Tonucci, F. (1991). Vyučovat nebo naučit? Praha: SVI PF UK.

Tupý, J. (2008). Dobrá škola. Podklad pro práci koordinační skupiny pro vyhodnocování kurikulární reformy. Praha: VÚP, nepublikováno.

Van den Akker, J. (1999). Principles and methods of development research. In J. van den Akker, N. Nieveen, R. M. Branch, K. L. Gustafson, \& T. Plomp (Eds.), Design methodology and developmental research in education and training (s. 1-14). Dordrecht: Kluwer Academic Publishers.

Veber, J. et al. (2005). Management. Základy, prosperita, globalizace. Praha: Management Press. 
Voda, J. (2010). Klíčové rozhodovací procesy při tvorbě školy a implementaci školního kurikula (Disertační práce). Praha: Univerzita Karlova, Fakulta pedagogická.

Wang, F., \& Hannafin, M. J. (2005). Design-based research and technology-enhanced learning environments. Educational Technology Research and Development, 53(4), 5-23.

\title{
Autor
}

PhDr. Jan Voda, Ph.D., Univerzita Karlova, Pedagogická fakulta, Katedra primární pedagogiky, M. D. Rettigové 4, 11639 Praha 1, e-mail: jan.voda@pedf.cuni.cz

\section{The managerial decision-making in school quality management}

\begin{abstract}
The paper presents some methodological applications of design-based research regarding the relation between managerial decision-making and the quality of a school. With the support of the theoretical principles of decision-making and the concept of a good school, we review the real effects of our decision-making processes in the phase of constituting a school and developing the school curriculum. The project is a private, bilingual primary school. The quality of the decision-making processes represents the basis of the quality of the school. During a 4 year period, we were observing and evaluating how the initial decisions were reviewed and changed during the cyclical process of analysis-design-evaluation-new design. Based on our process experience, we offer some interpretations which might contribute to wider understanding of decision-making processes of the management of schools. Concurrently, we make use of the research outputs to refine a practical solution to benefit the surveyed school.
\end{abstract}

Keywords: quality of school, primary school, curriculum, decision-making process, design-based research

Knotová, D. (2011). Pedagogické dimenze volného času. Brno: Paido.

Monografie se věnuje volnému času v pedagogické perspektivě. Zabývá se volným časem v širším pohledu jako prostorem umožňujícím rozvoj člověka prostřednictvím výchovy a vzdělávání. Celá publikace je rozčleněna do tř́ částí. Nejdříve je věnována pozornost fenoménu volného času, druhá část sleduje volný čas $\mathrm{v}$ pedagogické perspektivě včetně připomenutí možností a výzev pro pedagogické aktivity ve volném čase. Ve třetí části textu je předložena analýza současného stavu výchovy ve volném čase zaměřené na dětskou populaci v zemích Evropské unie a také analýza vybraných činností dospělých ve volném čase v ČR. 